\title{
ESTETIKA SIMBOLIK PADA DESAIN BANGUNAN KOMERSIL DI KAWASAN PERDAGANGAN CIHAMPELAS
}

\author{
Doni Morika \\ Jurusan Desain Interior, School of Design, Universitas Bina Nusantara \\ Jln. K.H. Syahdan 9, Kemanggisan/Palmerah, Jakarta Barat 11480 \\ donimorika@binus.ac.id
}

\begin{abstract}
The notion of aesthetics so far did not produce a conclusion crystallized from various points of view offered by observer. It came from the standpoint of behavioral and psychological environment to obtain the aesthetic sense which was based on the notion of meaning, perception, and aesthetic experience. In the philosophy of beauty "aesthetic experience" was in the view of phenomenology of the aesthetic experience of the "thing". Sensory aesthetic experience was based on observations at the same time with the whole soul of the human body and produced a feeling of participating bound, carried away, and enticed her feelings toward an aesthetic pleasure and experience. The question raised then is how these symptoms that could affect the behavior settings in the broad sense. Good answers to these questions will be able to make designers better understand the behavior of the users as well as empower designers to contribute to the environment.
\end{abstract}

Keywords: symbolical aesthetics, commercial buildings

\begin{abstract}
ABSTRAK
Pengertian estetika sejauh ini belum menghasilkan simpulan yang mengkristal sebagai hasil berbagai sudut pandang yang ditawarkan oleh pemerhati. Dari sudut pandang perilaku dan psikologi lingkungan, estetika memperoleh pengertian yang berlandaskan dari pengertian tentang meaning/makna, persepsi dan pengalaman estetika. Dalam filsafat keindahan "pengalaman estetis" menurut pandangan fenomenologi adalah merupakan pengalaman estetis tentang "thing". Pengalaman estetika berdasarkan pengamatan indrawi di saat yang sama keseluruhan jiwa-raga manusia turut berpartisipasi menimbulkan perasaan terikat, terhanyut, dan terpikat menuju suatu kesenangan dan pengalaman estetis. Pertanyaan yang mengemuka kemudian adalah bagaimana gejala tersebut dapat berpengaruh terhadap perilaku pengaturan dalam arti luas. Jawaban yang baik atas pertanyaan tersebut dapat membuat kita lebih memahami perilaku pengguna dan memberi andil desainer terhadap lingkungan binaan.
\end{abstract}

Kata kunci: estetika simbolis, bangunan komersial 


\section{PENDAHULUAN}

Istilah estetika dikemukakan pertama kali oleh Alexander Blaumgarten pada tahun 1750 untuk menunjukkan sebuah studi tentang taste di bidang seni rupa. Ilmu estetika berkait dengan mengidentifikasikan dan memahami faktor yang memberikan kontribusi pada persepsi suatu objek atau proses yang dianggap indah (beautiful) atau yang memberikan pengalaman yang bersifat menyenangkan. Secara etimologi kata tersebut berkaitan dengan segala sesuatu yang berhubungan dengan persepsi. Blaumgarten sendiri menaruh perhatian secara prinsip dengan persepsi beauty pada puisi, lukisan, dan seni patung.

Pada saat ini istilah tersebut digunakan secara meluas dalam diskusi permasalahan wujud nyata ataupun prosedural perancangan bangunan, interior, furnitur dan sebagainya. Istilah ini digunakan dalam pengertian pemahaman sifat kemampuan manusia untuk menciptakan dan menikmati display yang tercipta yang menyenangkan secara estetis.

Untuk menjelaskan apa yang dimaksud dengan estetika perlu diperhatikan terlebih dahulu pengertian-pengertian dasarnya. Dalam filsafat keindahan "pengalaman estetis" menurut pandangan fenomenologi merupakan pengalaman estetis tentang "thing". Pengalaman estetika berdasarkan pengamatan indrawi disaat yang sama keseluruhan jiwa-raga manusia turut berpartisipasi menimbulkan perasaan terikat, terhanyut dan terpikat perasaannya menuju suatu kesenangan dan pengalaman estetis.

\section{METODE}

Penelitian menggunakan metode kualitatif, yaitu dengan melakukan studi pustaka untuk mendapatkan konsep bangunan komersial, simbolik, dan estetika. Berbekal konsep tersebut dilakukan studi lapangan untuk mengobservasi bangunan komersial yang ada di kawasan perdagangan di daerah Cihampelas.

\section{LANDASAN TEORI}

Dari penjelajahan diatas tentang estetika yang terdapat pada olahan fasad bangunan di kawasan Cihampelas dari segi perencana (pengembang) maupun (calon) pengguna sedikit banyak telah dapat dinyatakan bahwa pendekatan estetika yang terdapat dan dilakukan terhadap perancangan dan pilihan bangunan tersebut mengarah kepada estetika simbolik sebagai dasar olahan estetika fasad bangunan (meskipun terdapat kepentingan yang berlawanan antara pengembang sebagai pedagang dan pengguna sebagai calon pemakai-nya) Kedua individu tersebut dapat dikatakan sepakat untuk mendudukkan kepentingan estetika simbolik sebagai landasan atas kesenangan estetika yang akan diperoleh dan ditampilkan pada bangunannya. Selanjutnya tentu saja akan membawa konsekuensi bahwa yang akan hadir nantinya diharapkan juga makna simbolik (apakah men-simbol-kangengsi, kekayaan, status adalah soal kemudian).

Mengenai makna ini tak kurang Hersberger menyatakan, “... Meaning is not contained in the elements of architecture, but rather something which is intended for attributed to them by human beings... (Robert G.Hersberger,1972). 
Tidak setiap susunan elemen dalam bangunan dapat mempunyai makna secara langsung tetapi makna ini timbul karena adanya kaitan bagaimana perlakuan manusia terhadap susunan tersebut. Setidaknya terdapat dua makna dalam ilmu arsitektur yang pertama adalah makna representational atau obyektif yaitu makna yang berkaitan dengan obyek, kejadian, ide atau sejenisnya yang merupakan faktor diluar manusia. Sedang jenis yang kedua adalah faktor makna responsif atau subyektif yang hanya berhubungan dengan faktor internal manusia berkaitan dengan emosi, tingkah laku, perasaan manusia itu sendiri.

Lingkungan binaan sekitar kita penuh dengan makna simbolik dengan segala pengaruhnya terhadap individu sekeliling. Pengenalan terhadap makna ini disadari atau setengah disadari memberi pengaruh terhadap perasaan individu tentang lingkungan dan pemikiran tentang eksistensi dirinya sendiri. Makna simbolik selama ini belum merupakan masalah yang perlu disinggung, padahal pengenalan terhadap makna simbolik dari lingkungan binaan adalah hal yang cukup penting dimana dengan mengenal tersebut individu dapat memproleh capaian kearah "rasa memiliki" ( sense of belonging ) atas tempat dan kaitan dirinya dengan kelompoknya, demikian dinyatakan oleh Amos Rapoport (1982).

Sifat dari simbol yang sering dinyatakan dalam ilmu yang disebut sebagai semiology adalah lahan yang kerap mempengaruhi para arsitek dan designer lingkungan (seperti Broadbent, Bunt dan Jencks). Perhatian utama dari semiology adalah pada segitiga semiologikal yang merupakan hubungan antara symbol, though, dan referent seperti yang ternyatakan dalam Gambar 1.

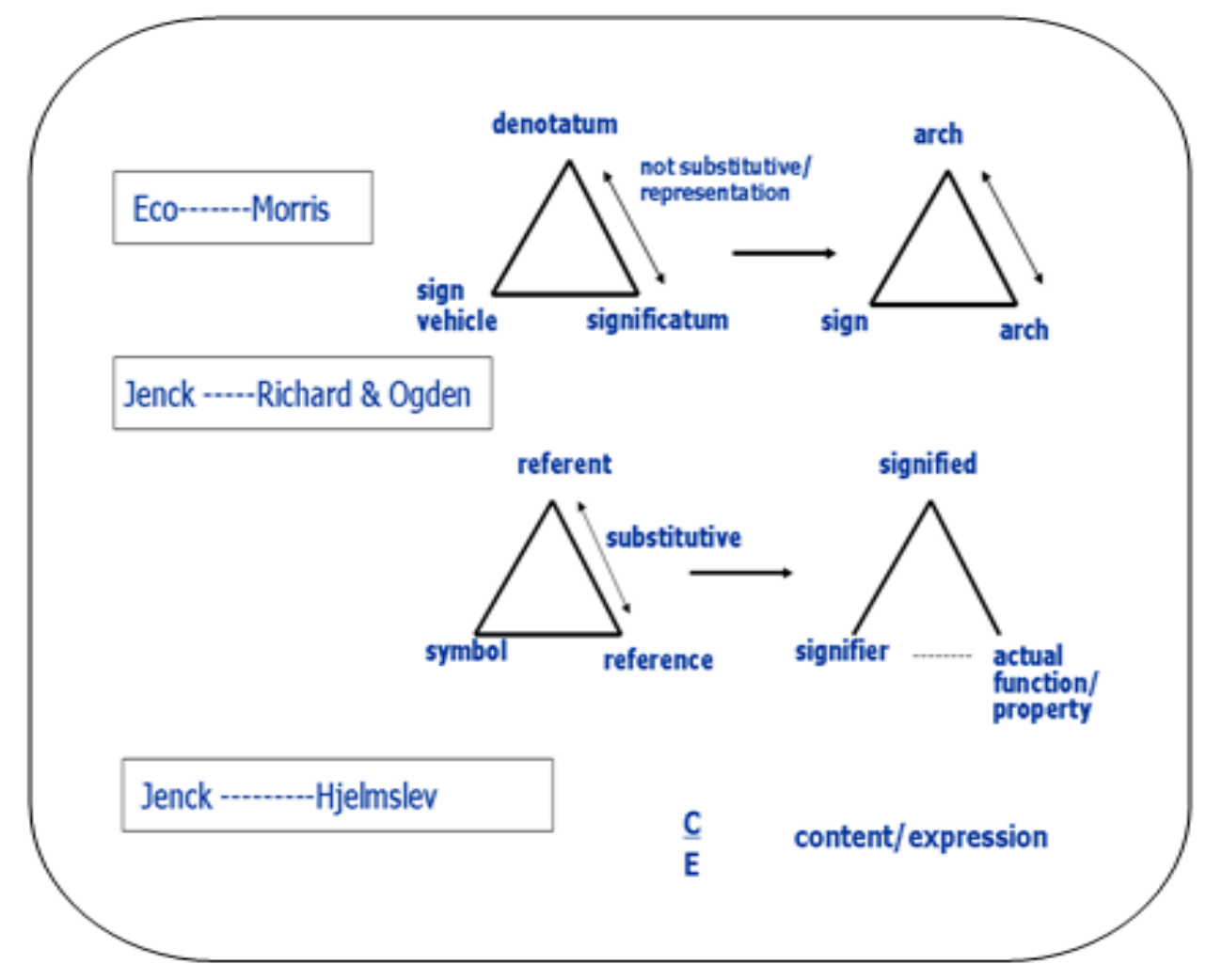

Gambar 1 Segitiga Semiologikal 
Lingkungan binaan mengandung struktur atau susunan permukaan berbagai material bahan , pigmentasi dan tingkatan iluminasi. Pola elemen tersebut merupakan penanda atau signifier. Idea dan makna yang berkaitan dengan pola ini yang merupakan pertanda (signified) - mungkin mempunyai keragaman antar individu karena referensinya yang berlainan. Referensi ini yang membuat eksperiensi atas berbagai makna dan estetika mempunyai kemungkinan untuk berlainan.

Karenanya jika ditinjau dari bentuk bangunan komersil pada kawasan Cihampelas belakangan ini muncul beraneka ragam gaya dan model berikut.

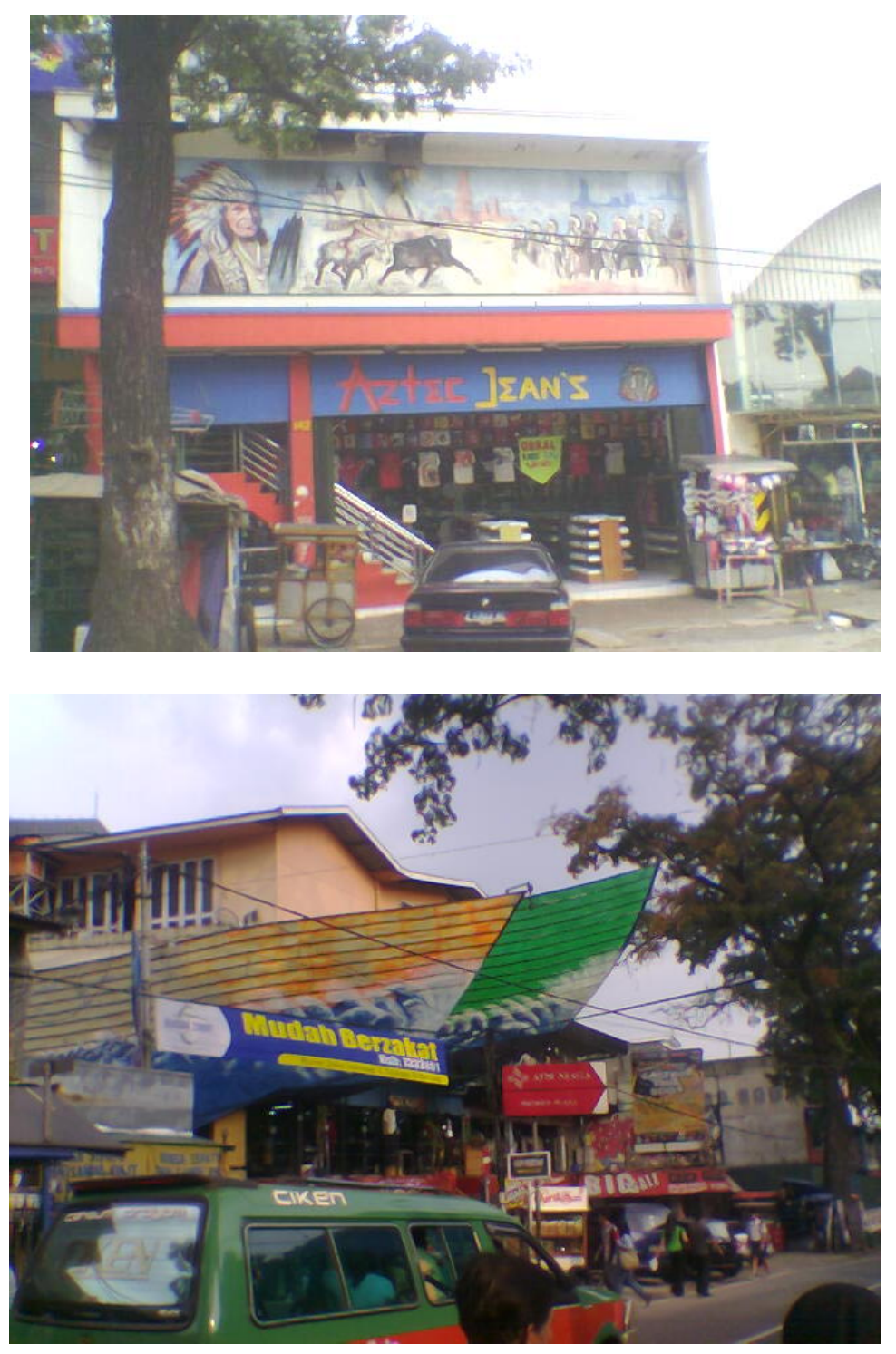

Gambar 2 Banguman Komersial di Cihampelas 
Makna simbolik juga tergantung dari konteksnya. Charles Moore (1938) menyatakan sekurangnya terdapat tiga tingkatan makna yaitu : syntactic, semantic dan pragmatic. Makna syntactis dihasilkan dari lokasi bangunan terhadap sekelilingnya. Makna semantic merujuk pada norma , ide atau sikap yang muncul dari penampilan elemen bangunannya. Makna pragmatic berkaitan langsung dengan simbol-simbol yang digunakannya dalam bangunan tersebut. Dengan konteks yang demikian maka makna simbolik yang muncul dari penampilan fasade bangunan adalah makna syntactis yang tak dapat dipungkiri lagi bahwa penampilan bangunan yang khas daerah perbelanjaan Cihampelas.

Proses stimulus dan respon secara umum menerangkan mengapa beberapa perbedaan interpretasi tentang simbol dapat muncul. Sudah lazim diketahui bahwa variabel yang sama (seperti fasad bangunan) mungkin akan memberikan makna yang berlainan bagi pengamat yang berbeda. Di sisi lain bentuk yang berbeda mungkin juga akan mampu mengkomunikasikan makna yang sama. Dalam masyarakat yang homogen terdapat kesepakatan umum dalam simbolisasi tentang bangunan yang spesifik dalam gaya ataupun dekorasinya. Ketika pengalaman dan nilai berkembang maka akan muncul kemungkinan kebedaan makna terhadap pola yang sama. Teori desain membutuhkan untuk mengenali hal ini karena makna simbolik menyediakan sejumlah sasaran bagi masyarakat dan menjadi hal yang penting dalam beberapa hal tertentu.

Suzanne Langer (1993) menyatakan bahwa "Human being are symbol mongers". Salah satu cara manusia berkomunikasi adalah dengan menggunakan simbol. Makna simbolik ini adalah mekanisme non verbal yang digunakan untuk menyampaikan pesan tentang diri manusia, latar belakang, status sosial, dan pandangan hidupnya.

Dalam studinya tentang Las Vegas, Robert Venturi (1962-64) menyatakan bahwa isi dari simbol (di Las Vegas) adalah kemasan dari pemasaran komersial secara artifisial dari kalangan jet-set, yang terjadi adalah pengabaian aspirasi simbolik dari kalangan menengah oleh kebanyakan perancang urban. Mereka mengenali simbol itu namun tidak menerimanya apalagi mau memanfaatkannya. Bagi mereka dekorasi simbolik dari lapisan kelas sub-urban menampilkan derajat yang rendah karena semuanya dinilai berdasarkan materi dan konsumerisme. Jika dicermati maka gejala ini juga melanda kawasan perbelanjaan Cihampelas.

Pertanyaan yang mengemuka kemudian adalah bagaimana gejala tersebut dapat dengan cepat melanda dan menjadi trend setter?. Bagaimana pengaruhnya terhadap pengaturan prilaku dalam arti luas? Jawaban yang baik atas pertanyaan tersebut akan dapat membuat arsitek memahami lebih baik perilaku penggunanya serta andil arsitek terhadap lingkungan. Hanya saja ketrampilan menjawab pertanyaan tersebut kian langka belakangan ini.

Makna simbolik masyarakat diperoleh dari lingkungan alami maupun lingkungan binaan dari nilai-nilai yang disandangnya. Ini disadari atau tidak tergantung pada siapa mereka secara physiologikal , sosial dan psikologikal. Inilah yang mendasari perbedaan dalam nilai estetika simbolik masing-masing. Perbedaan ini mempunyai sifat yang bervariasi dalam karakter organisme. Disana juga terdapat kelompok masyarakat yang mempunyai perbedaan konsep tentang estetika dalam berbagai tipe.

\section{HASIL DAN PEMBAHASAN}

Cihampelas secara tidak langsung adalah perwujudan arsitektur sebagai komoditi. Setiap proses kreatifvitas yang berlangsung di Cihampelas, sejak awal diarahkan dalam rangka menciptakan bentuk estetisme dengan fungsi simbolik untuk menaikkan nilai komersial sebuah tempat yang mewadahi aktivitas perdagangan. Dalam hal ini, tempat yang menarik diyakini akan mendatangkan 
pengunjung, untuk itu setiap bangunan baru di Cihampelas harus berbeda dengan yang telah ada. Diferensi penampakan ditempuh dalam rangka menyusun suatu aura komoditi, semangat yang membuat setiap arsitektur postmodern menjadi menarik dan menggoda. Setiap aura komoditi yang diupayakan pada sebuah komposisi facade tidak memiliki hubungan apapun dengan karakter atau ciri celana jeans sebagai onjek yang berkaitan langsung dengan aktivitas utama.

Estetika Cihampelas adalah sebentuk tontonan yang mencerminkan pengalaman kultural terwujud dalam citra-vitra, karakter populer yang berasal dari wilayah pengekspor budaya, terutama pada kasus ini adalah Amerika dan Jepang.

Penampakan bangunan pada kawasan perbelanjaan Cihampelas adalah sebentuk fashion yang berkiblat, bergantung kepada kemunculan idiom baru yang diproduksi di wilayah pengekspor budaya ( seperti munculnya Hercules, Ultraman, dll ). Model kreativitas ini adalah semacam model kreativitas yang lebam, tanpa akhir.

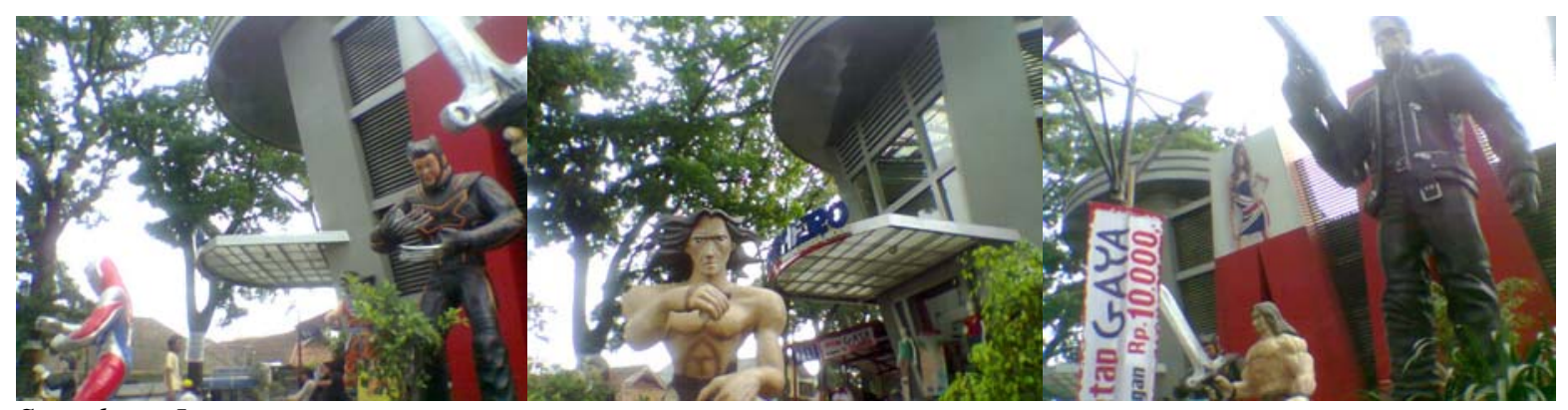

Superhero Jeans

Gambar 3 Model Kreativitas di Kawasan Cihampelas

Model estetika arsitektur yang ditampilkan oleh bangunan-bangunan di Cihampelas tidak berkaitan dengan realitas, dan masing-masing merupakan tanda bagi dirinya sendiri. Cihampelas adalah contoh bagi apa yang disebut Jean Baudrillard sebagai patung atau tiruan. Identitas kawasan Cihampelas dibentuk melalui proses-proses simulasi. Simulasi tersebut ditempuh dengna merujuk kepada film, komik, kartun, dan sebagainya, sehingga fiksi dan fantasi menjadi referensi utama bagi kreativitas estetik di Cihampelas. Dalam pengertian ini, kawasan Cihampelas adalah sebuah ruang hipereal, sebuah ruang kontemporer yang dilingkupi objek patung atau tiruan postmodern.

\section{SIMPULAN}

Estetika Simbolik pada tampilan arsitektur adalah salah satu dari pusat perhatian untuk apresiasi estetis. Pilihan masyarakat dalam mengolah lingkungan untuk mereka tempat tinggali seringkali berlandaskan pada hal yang simbolik. Amos Rapoport menegaskan bahwa dengan merubah simbol yang bersesuaian dan menjadi karakter suatu tempat, juga akan merubah persepsi manusia terhadap kualitas ruang. Perancang lingkung bina seringkali berusaha untuk menciptakan simbol baru dengan memanipulasi variabel bentuk bangunan dengan intuisi yang cukup baik meskipun ini mempunyai tingkat kesulitan yang cukup tinggi dalam menangani dan menggunakan simbol sebagai landasan meraih estetika suatu lingkungan binaan. 


\section{DAFTAR PUSTAKA}

Brodbent,G., \& Jencks, C. (1980).Sign, Symbol and Architecture. New York: JohnWiley.

Hersberger, R.G. (1974). Predicting the Meaning of Architecture. In Stroudsburg. DH and Ross Designing for Human Behavior.

Langer, S.K. (1953). Feeling and Form.a Theory of Art. New York: Charles Sibner’s Sons.

Venturi, R. et.al. (1977). Learning from Las Vegas. Cambridge.Mas: MIT Press.

Yasraf Amir Piliang, power point Semiotika Arsitektur. 